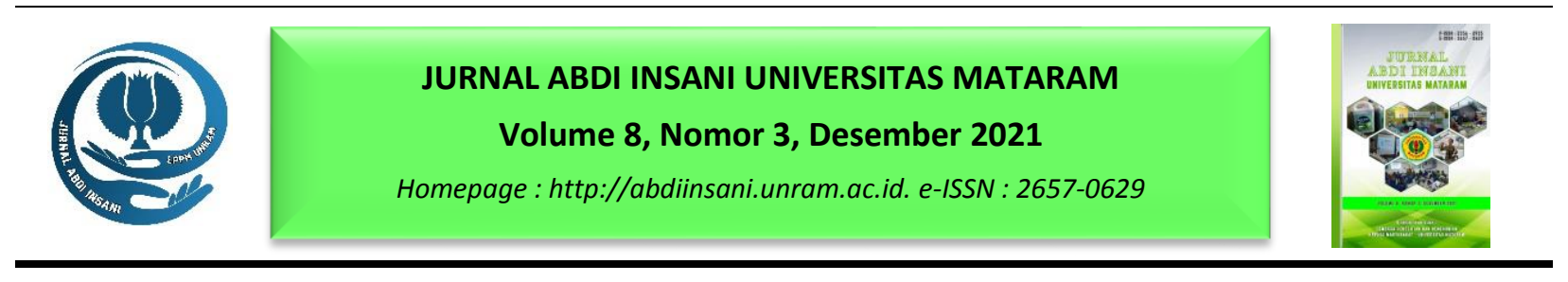

\title{
PELATIHAN TERAPI OKSIGEN PADA TENAGA KESEHATAN DI RUMAH SAKIT UMUM UNIVERSITAS MATARAM
}

\section{Oxygen Therapy Management Training for the health personnel of Mataram University Hospital}

\author{
Moulid Hidayat, Prima Belia Fathana, Devi Ramadhona, Wahyu Sulistya Affarah \\ Program Studi Pendidikan Dokter, Fakultas Kedokteran Universitas Mataram, Mataram \\ Indonesia
}

\section{JI. Pendidikan Nomor 37 Kota Mataram, NTB}

Alamat korespondensi : moulid.hidayat.md@unram.ac.id

(Tanggal Submission: 10 Desember 2021, Tanggal Accepted : 29 Desember 2021)

\begin{abstract}
Kata Kunci : Abstrak :
pelatihan

Oksigen merupakan substrat penting bagi kehidupan manusia. Pengambilan terapi oksigen dari lingkungan melalui kerja paru memberikan asupan substrat penting oksigen, untuk proses produksi energi. Pada kondisi gawat napas, pemberian oksigen tenaga merupakan hal yang sangat esensial untuk menjaga homeostasis tubuh dan kesehatan, mencegah kerusakan organ lebih lanjut.Sehingga, Bagi tenaga kesehatan, terapi oksigen informasi tentang indikasi pemberian oksigen, berapa dosis oksigen yang tepat, bagaimana cara memberikan oksigen yang benar, dan apa yang harus diperhatikan dalam pemberian oksigen sangat perlu dikuasai dengan baik. Kegiatan pengabdian kepada Masyarakat ini bertujuan untuk meningkatkan pengetahuan tenaga kesehatan di Rumah Sakit Universitas Mataram mengenai terapi oksigen. Kegiatan pelatihan ini dilakukan dengan menggunakan metode ceramah interaktif dan dilanjutkan dengan sesi tanya jawab dan diskusi. Pengetahuan peserta dinilai berdasarkan pre-test dan post-test. Kegiatan pelatihan dihadiri oleh 34 orang tenaga kesehatan yang khusus berasal dari instalasi rawat isolasi, instalasi gawat darurat, dan instalasi perawatan kritis (intensive care unit (ICU)) Rumah Sakit Universitas Mataram. Pada pelatihan ini, peserta disuguhkan materi mengenai indikasi pemberian oksigen, dosis oksigen, cara memberikan oksigen dengan berbagai macam device, dan apa yang harus diperhatikan dalam pemberian terapi oksigen. Dari hasil olah statistik diperoleh data peningkatan pengetahuan yang bermakna, dengan selisih skor peningkatan pengetahuan sebesar $10.89 \quad(p=0.0225 \quad(<0.05), 95 \%$ KI 1.551-
\end{abstract}


19.06). Peningkatan pengetahuan tenaga kesehatan melalui kegiatan pelatihan terapi oksigen dibutuhkan untuk pelayanan kesehatan sehari-hari pasien dengan kegawatan napas.

Panduan sitasi / Citation guidance (APPA $7^{\text {th }}$ edition) :

Hidayat, M., Fathana, P. B., Ramadhona, D., \& Affarah, W. S. (2021). Pelatihan Terapi Oksigen

Pada Tenaga Kesehatan Di Rumah Sakit Umum Universitas Mataram. Abdi Insani, 8 (3), 337-341. http://doi.org/10.29303/abdiinsani.v8i3.442

\section{PENDAHULUAN}

Oksigen merupakan substrat yang penting bagi makhluk hidup (Rogayah \& Rasmin, 2010). Oksigen dibutuhkan oleh tubuh untuk menghasilkan energi. Kekurangan oksigen dalam darah disebut dengan hipoksemia (West, 2013). Keadaan hipoksemia yang berkelanjutan dapat mengakibatkan hipoksia jaringan yang dapat berakhir dengan kematian jaringan (West, 2013). Pada era pandemi Covid-19, pasien dengan gejala covid-19 sedang, berat dan kritis sangat membutuhkan asupan oksigen (Sardesai et al., 2020). Oksigen merupakan suatu obat. Selayaknya obat, oksigen memiliki dosis tertentu dan efek samping (Rogayah \& Rasmin, 2010). Jika oksigen tidak diberikan dengan dosis yang adekuat, maka akan terjadi ketidak seimbangan kebutuhan dan asupan yang berimbas pada hipoksi jaringan, dan kerusakan organ.

Pemberian oksigen dengan dosis yang berlebih harus dihindari sebab pemberian oksigen dilakukan dengan berlebihan akan berimbas pada kondisi hiperoksia. Kondisi hiperoksia ini dapat berakibat pada kondisi yang kritis akibat terjadinya kerusakan akut jaringan paru akibat pembentukan radikal bebas, juga dapat terjadi vasokonstriksi pembuluh darah secara difus yang berakibat pada kekurangan asupan oksigen pada jaringan (Rogayah \& Rasmin, 2010; West, 2013). Oleh karena pentingnya tatalaksana oksigen pada kondisi hipoksemia, terutama pada pasien-pasien Covid-19 yang membutuhkan oksigen di era pandemi ini, sehingga diperlukan pemahaman yang baik tentang terapi oksigen dikalangan tenaga kesehatan yang merupakan lini terdepan dalam penanganan pasien Covid-19. Diperlukan pelatihan dan penyegaran kembali mengenai apa indikasi, dosis, cara pemberian serta kontraindikasi pemberian oksigen. Harapannya dengan penyegaran kembali mengenai seluk beluk terapi oksigen, tenaga kesehatan dapat memiliki dasar pemahaman yang kuat, dan cakap dalam memberikan terapi oksigen kepada pasien.

\section{METODE KEGIATAN}

Kegiatan pelatihan terapi oksigen dilakukan dalam bentuk ceramah interaktif. Kegiatan ini secara umum terdiri dari sesi penyampaian materi oleh pemateri, dan tanya jawab oleh peserta. Proses tanya jawab dapat berlangsung di tengah penyampaian materi dan di akhir penyampaian materi, yaitu dalam sesi diskusi, tanya jawab. Penilaian tingkat pengetahuan peserta tentang materi dilakukan dengan penyelenggaraan pre-test dan post-test. Hasil pre- dan post-test kemudian dianalisis menggunakan software statistik Graphpad?]. Ceramah berlangsung dalam suasana yang kondusif, diskusi berlangsung dengan hangat, dan ceria. Secara rinci kegiatan pelatihan berlangsung dalam 3 tahap, yaitu: 1) tahap perkenalan dan penyampaian materi. Pada tahap ini peserta diminta untuk mengutarakan harapanharapan yang ingin dicapai setelah mengikuti pelatihan ini. Kemudian dilanjutkan dengan penyampaian materi inti oleh pemateri. Materi yang disampaikan dalam bentuk ceramah interaktif yang berisikan definisi, indikasi, kontraindikasi terapi oksigen. 2) tahap evaluasi pengetahuan peserta pelatihan. Pada tahap ini, tingkat pengetahuan peserta pelatihan dinilai dengan mengadakan pre-test dan post-test. 


\section{HASIL DAN PEMBAHASAN}

Kegiatan pelatihan oksigen pada tenaga kesehatan di RS Universitas Mataram berlangsung pada tanggal 25 September 2021 di Aula lantai 2 RS Universitas Mataram. Kegiatan ini diikuti oleh 34 orang peserta yang berasal dari tiga unit kerja yaitu, unit perawatan intensif, unit perawatan isolasi Covid-19, dan unit gawat darurat. Peserta hadir tepat waktu dan kegiatan pelatihan dimulai sesuai dengan jadwal. Setiap panitia dan peserta wajib mematuhi protokol kesehatan karena kegiatan berlangsung masih dalam kondisi pandemi. Panitia dan peserta menjalani skrining Covid-19 sederhana dengan pengukuran suhu. Seluruh peserta dan panitia telah mendapatkan vaksin Covid-19 lengkap. Selain itu peserta dan panitia juga wajib untuk melakukan cuci tangan sebelum kegiatan berlangsung, menggunakan masker serta menjaga jarak satu sama lain selama kegiatan berlangsung. Ruangan pelatihan didesain untuk memungkinkan peserta duduk dengan jarak 1 meter dari peserta lainnya.

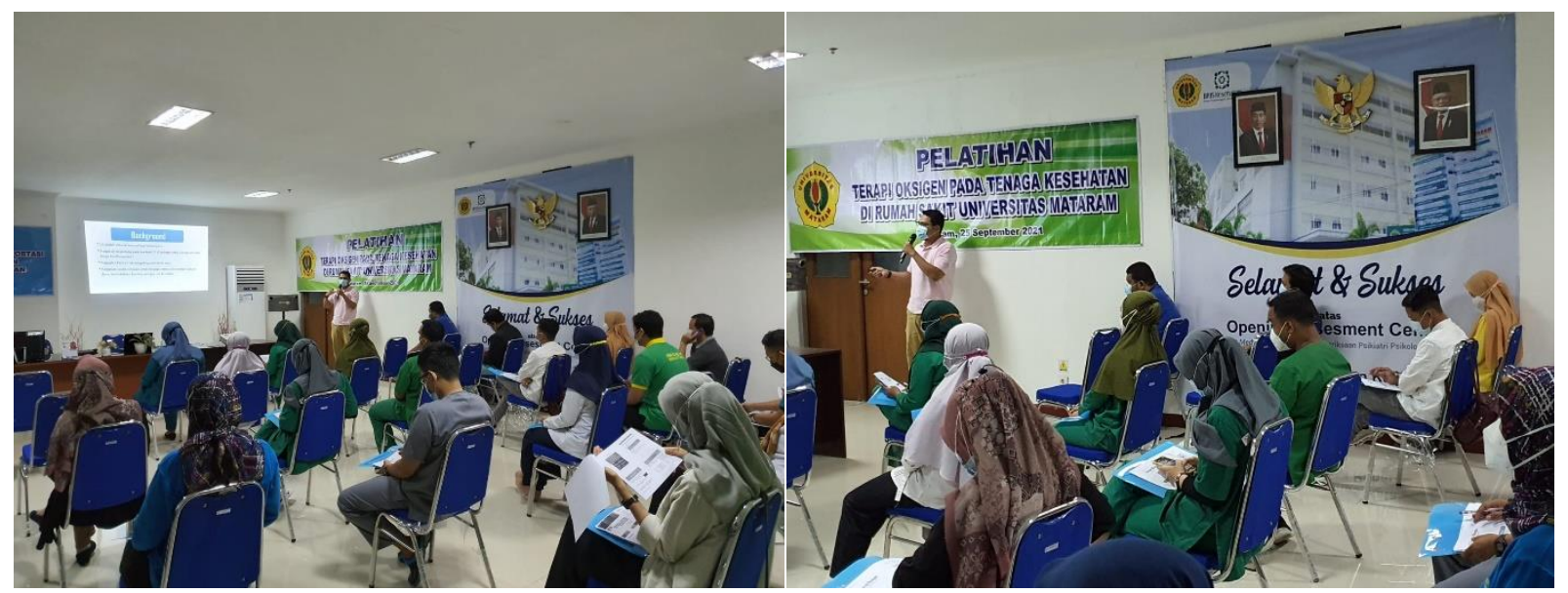

Gambar 1. Kegiatan pelatihan terapi oksigen di Aula It.2 RS Universitas Mataram

Pada kegiatan pelatihan terapi oksigen ini, peserta dibekali informasi mengenai indikasi-indikasi terapi oksigen seperti pada pasien dengan kondisi gawat napas, hipoksemia, hipoksia, dan gagal napas. Peserta juga mendapatkan informasi mengenai pemberian dosis oksigen yang adekuat, cara menentukan kebutuhan oksigen pasien secara kasar. Sebagai contoh pasien dengan penyakit penyempitan saluran napas bawah yang kronik, seperti pada penyakit paru obstruksi kronik (PPOK) maka pemberian oksigen pada pasien tersebut tidak boleh berlebihan, karena justru dapat menimbulkan komplikasi yang merugikan pasien, dan sebagainya. Cara pemberian dan alat yang digunakan juga dibahas pada pelatihan ini, serta kontrandikasi dan hal yang harus diperhatikan dalam pemberian oksigen juga disampaikan ke peserta pelatihan.

Terdapat 4 penanya saat sesi diskusi. Peserta sangat antusias dalam bertanya. Pertanyaan yang diajukan seputar kondisi sehari-hari dalam menghadapi pasien Covid-19 dan pasien dengan gawat napas. Acara selanjutnya dilanjutkan dengan post-test. Kegiatan pelatihan oksigen diakhiri dengan pengumuman peserta terbaik dengan hasil post-test tertinggi serta pembagian bingkisan kenang-kenangan dari panitia penyelenggara kegiatan kepada peserta terbaik. Seperti yang telah disampaikan pada paragraf sebelumnya bahwa kegiatan pre-test dan post-test dilakukan untuk menilai tingkat pengetahuan peserta pelatihan sebelum penyampaian materi dan setelah penyampaian materi. Materi soal pre- dan post-test terdiri dari 10 soal pilihan ganda, yang mewakili isi dari materi pelatihan yang disampaikan pada kegiatan ini. Sebaran nilai pre-test dan post-test dapat dilihat pada gambar 2 dan gambar 3. 


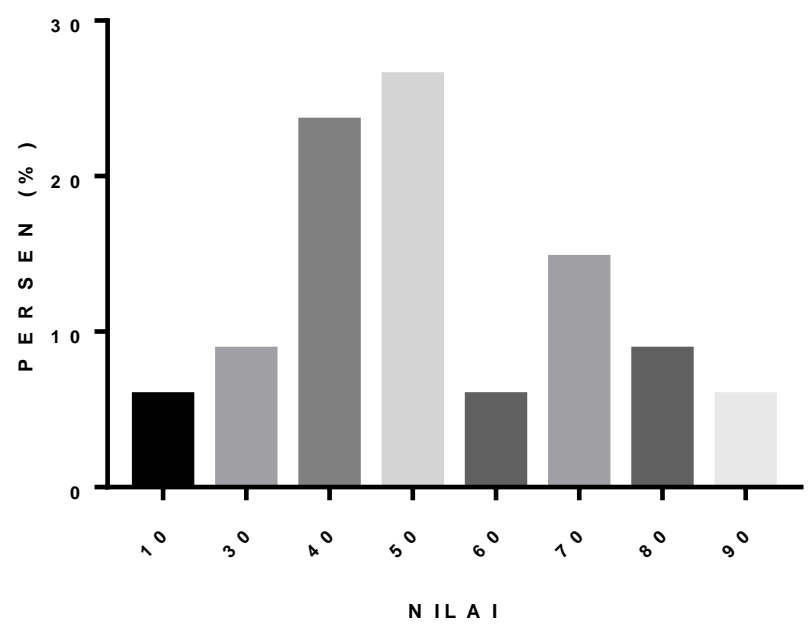

Gambar 2. Nilai pre-test peserta pelatihan terapi oksigen

POS T-TEST

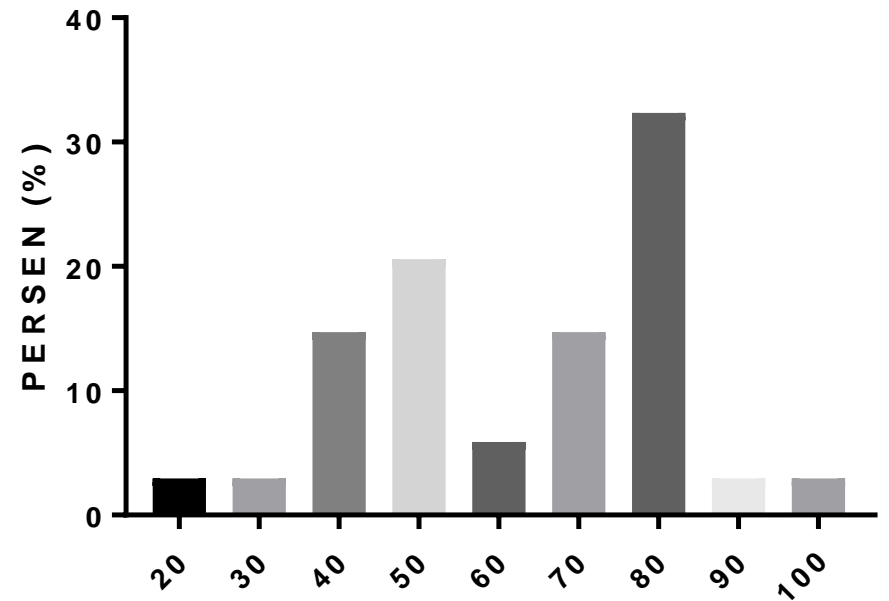

NILA I

Gambar 3. Nilai post-test peserta pelatihan terapi oksigen

Pada gambar 2 dan gambar 3, nilai terrendah pre-test adalah 10, dan pada post-test adalah 20. Nilai tertinggi pada pre-test adalah 90, dengan sebaran nilai terbanyak adalah 40 dan 50 . Sedangkan pada post-test, nilai tertinggi adalah 100 dengan sebaran nilai terbanyak adalah 80 . Analisis dilanjutkan dengan uji komparatif menggunakan uji t berpasangan didapatkan skor selisih pengetahuan sebelum dan sesudah alih pengetahuan ialah 10.89 poin dan didapatkan perbedaan yang bermakna pengetahuan peserta pelatihan oksigen sebelum penyampaian materi dan setelah penyampaian materi (nilai $p<0,05$ ). Hasil analisis lengkap ditampilkan pada gambar 4. 


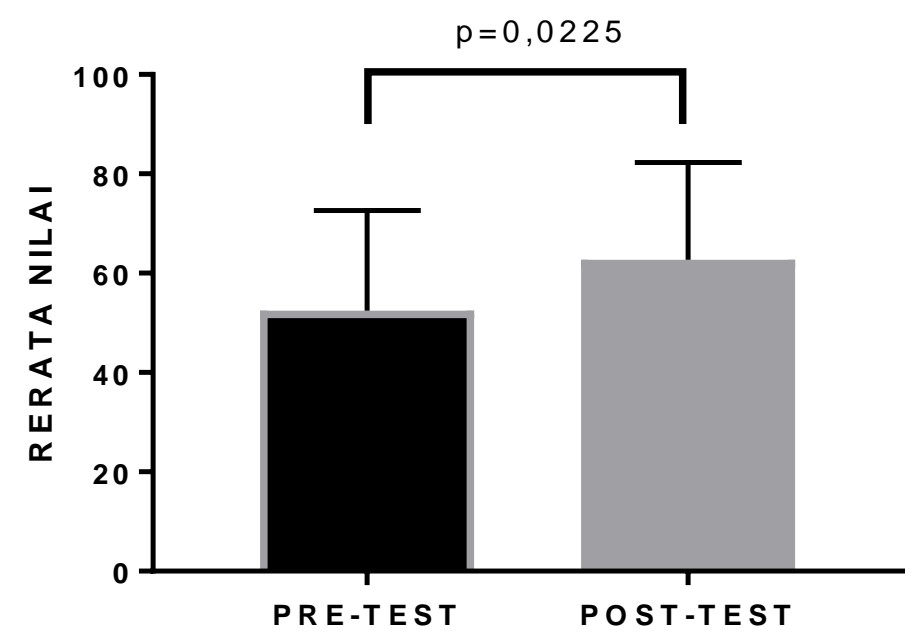

Gambar 4. Analisis hasil alih pengetahuan pelatihan terapi oksigen

\section{KESIMPULAN DAN SARAN}

Kesimpulan kegiatan pengabdian kepada masyakarat ini adalah terdapat peningkatan pengetahuan yang bermakna pasca dilakukan penyampaian materi terapi oksigen pada tenaga kesahatan. Saran yang dapat diambil adalah : untuk mencapai pelayanan yang paripurna terhadap kasus kegawatan respirasi diperlukan kegiatan alih pengetahuan pada tenaga kesehatan tentang terapi oksigen.

\section{UCAPAN TERIMA KASIH}

Penulis mengucapkan syukur yang mendalam kepada Tuhan yang Maha Esa, juga kepada RS Universitas Mataram khususnya bagian Pendidikan dan Pelatihan atas dukungannya dalam penyelenggaraan kegiatan pengabdian kepada masyarakat ini. Kegiatan dalam bentuk penyegaran pengetahuan tentang terapi oksigen di kalangan tenaga kesehatan RS Universitas dapat berjalan dengan baik. Ucapan terimakasih juga kami sampaikan kepada seluruh peserta pelatihan yang sangan antusias mengikuti acara pelatihan sampai dengan akhir kegiatan.

\section{DAFTAR PUSTAKA}

Rogayah, R., \& Rasmin, M. (2010). Terapi oksigen. Dalam : Pulmonologi intervensi dan gawat darurat nafas. Jakarta (ID) : Universitas Indonesia Press.

Sardesai, I., Grover, J., Garg, M., Nanayakkara, P. W. B., Di Somma, S., \& Paladino, L. (2020). Short Term Home Oxygen Therapy for COVID-19 patients : The COVID-HOT algorithm. J Family Med Prim Care, 9(7), 3209-3219.

West, J. B. (2013). Pulmonary Pathophysiology The Essentials 8th edition. China : Lippincott Williams \& Wilkins. 